\title{
Staging Teachers' Stories: Performing Understandings of Writing and Teaching Writing
}

\author{
MICHELLE A. HONEYFORD \\ University of Manitoba \\ WAYNE SEREBRIN \\ University of Manitoba
}

\begin{abstract}
In response to concerns about declining writing instruction in K-12 classrooms, this qualitative interview study draws on research-based theatre to better understand teachers' experiences teaching writing in one Canadian province. Through dramaturgical coding of transcripts, we examine teachers' objectives, conflicts, and tactics in teaching writing, as well as the significant role of educators' subjectivities as writers and writing teachers, the settings in which they work, the people who influence their thinking and practice, and their engagement in reflexive inquiry. Two drama-based vignettes explore these themes. We then discuss implications for creating a province-wide professional learning network in critical writing pedagogies.
\end{abstract}

As literacy researchers and teacher educators with close ties to schools, community, and professional education organizations, we began this study with general impressions about the current landscape of writing education in the province. We had observed that writing workshops once commonplace in the province were now a rarity, and it seemed to us that writing pedagogy had been pushed to the margins of curriculum. Across grade levels, in locations where attention to the teaching of writing had persisted, it appeared to have become increasingly standardized and prescriptive. And consistent with researchers' findings beyond our provincial and national borders, we had noticed and heard from local educators that many students, of all ages, faced a "writing diet that [was] formulaic . . . [did] not connect to their lives, and [did] not provide opportunities to grapple with, and think on paper about, socially significant issues and ideas" (Flint \& Laman, 2014, p. 72).

As a check on these assumptions, we were fortunate to have professional relationships with practitioners across the province, known to us (and to local practitioners) for their passion for writing, advocacy and alliances with their students, and commitment to create meaningful writing engagements. It was to these practitioners and their "insider perspectives" (Cochran-Smith \& Lytle, 1993) that we turned in order to better understand the shifting landscape of writing education. We hoped to gain insights about the kinds of professional learning resources, supports, and networks that would be necessary to revive the rich writing legacy of the province and to set a future course for writing pedagogies that call "critical understandings of language, text, discourse and subjectivity" into classroom practice (Kamler, 2001, p. x). 
We approached the research with these questions in mind:

1. How do educators in a wide range of contexts, and with a diverse array of professional experiences, theorize writing and the teaching of writing?

2. To what extent do teachers understand and situate their subjectivities and pedagogies as writing teachers in relationship to their own writing experiences, the diverse contexts in which they teach, the range of identities claimed by their students, and their efforts to help their students navigate the literacy gaps between their home and/or community and school?

3. How well do educators' theories and pedagogies fit with the literacy and writing curricular expectations of the province, school divisions, and local communities? What tensions, if any, do teachers experience? How do they respond?

4. What are the implications that need to be considered in seeking to create a sustainable professional learning network that engages in critical writing pedagogies?

\section{Local Knowledge of Practice}

\section{Theoretical Framework}

Through the study, we sought to critically explore teachers' "local knowledge of practice" (Cochran-Smith \& Lytle, 1999) about writing. Many of these teachers had been engaged in sustained inquiries of their practice through their participation in teacher inquiry groups, formal and informal professional learning communities, and graduate coursework and research. The study grew from wanting to learn from them about "what is going on here" in the province around writing (Cochran-Smith \& Lytle, 1993, p. 47). We sought to understand what the teaching of writing looked like in and across multiple contexts, recognizing that educators "who work...and/or who live in particular social situations have significant knowledge about those situations" (Cochran-Smith \& Lytle, 2009 , p. 42). Theorizing knowledge as local knowledge of practice shifts the epistemic reference point of research (i.e., from what is known by experts based on research somewhere else) to practitioners' own knowledge, to their understandings of their students "as knowers", and to the knowledge generated through systematic studies of their own practice (Cochran-Smith \& Lytle, 1993, p. 52).

\section{Writing as Situated, Social Practices}

Theoretically, we understand writing as situated, social practices of written communication that include print and combinations of print and other semiotic systems and modalities (e.g., colour, image, iconography) (see Street, 1984; Gee, 1990; Kress, 2009). Theorizing writing in this way signals a shift away from understanding writing as a discrete set of skills students need to learn, and towards understanding writing as the practices we and our students utilize in our everyday lives to communicate with others. This has implications for how writing is taught (i.e., pedagogy) and the scope, sequence, and variety of guidelines, outcomes, standards, assessments, and materials we use to teach writing (i.e., the curriculum). For when we assume that "students need to be 'fixed,' invariably we design curriculum that erases students' home language and culture; we fail to find the strength and beauty in the experience and heritage that students bring with them to school" (Christensen, 2009, p. 2). Theorizing writing from a sociocultural 
practice perspective re-centers the focus of writing pedagogy around students and their identities as writers. Teachers' roles — which can also be relegated to the periphery - once again occupy "the central position ... as knowers", with the opportunity and the responsibility to mobilize the "transformative power of local knowledge in justice-related efforts to improve students' learning and enhance their life chances" (Cochran-Smith \& Lytle, 2009, p. 127).

\section{Critical Writing Pedagogies}

The selection of the province's capital city as the site of the new Canadian Museum of Human Rights has sparked a great deal of discourse recently in the province about the teaching of human rights and social justice. Issues of social justice and human rights are central to critical literacy (Freire, 1970/2000), which in Freirean terms is about teaching students to read the word and the world. In this study, more specifically, we theorize critical writing pedagogies as "political project[s] in schools and communities" (Fine, 2001 forward, p. ix). With Kamler (2001) we argue for "bringing together a variety of writing pedagogies that cross boundaries-including process and genre-based approaches ... with elements of poststructural theory" (p. 2-3), understanding writing through cultural, spatial, and poststructural frames so that writing "becomes an invitation to identify, analyse and critique, to understand the discursive practices that construct the sense of the self — which in turn offer possibilities for social change" (Kamler, 2001, p. $3)$.

The practitioners we interviewed were deeply involved in critical pedagogical work. For example, their practices deliberately surfaced the lingering colonial history in the everyday realities of the 63 First Nations and non-Aboriginal peoples of our province, or involved them as educators in sociocultural and linguistic bridging relationships with growing numbers of students and families who were making the province their home (as some fled genocide and civil war in their own countries). For these practitioners, writing and writing pedagogy embodied their understandings of critical literacy - "the use of the technologies of print and other media of communication to analyze, critique, and transform the norms, rule systems, and practices governing the social fields of institutions and everyday life" (Luke, 2014, p. 21). This was particularly significant in that "writing pedagogies, for the most part, have not called upon critical understandings of language, text, discourse and subjectivity ... [into] classroom practice” (Kamler, 2001, p. 8).

\section{Positioning as Researchers}

\section{Methodology}

Our own collective experiences teaching writing include working in classrooms on oral storytelling, drawing, dramatization, and writing as integrated processes in multiple languages and modalities. In various projects and capacities and at levels from PK-12, we have worked alongside students and teachers in diverse contexts-early childhood centres, afterschool programs, alternative schools, multiage and inquiry classrooms, English as an Additional language classrooms, First Nations band-operated schools, community adult education programs, university-school partnerships, and interinstitutional forums - to support writers and the teaching of writing. We have explored writing with students and teachers as a means of transdisciplinary inquiry, initiated writing clubs, taught composition and college writing courses, and created supportive 
spaces for ourselves and other educators to explore our intersubjective voices in engagements with "life writing" (Chambers, Hasebe-Ludt, Leggo, \& Sinner, 2012; Hasebe-Ludt, Chambers, \& Leggo, 2009).

These experiences have situated our understandings of writing and writing pedagogy in specific ways. We recognized, then, the need to complicate and push our own "knowing" and assumptions about writing and writing pedagogy through the knowledge, experiences, and ideas of a diverse group of educators. In our efforts to initiate a province-wide writing network, we approached this study as an opportunity to open up a wider epistemic and ontological space through interviews with practitioners that would include, respect, and bring into dialogue "the necessary entanglements of epistemologies - how we claim to 'know' about something or someone; and ethics - how we come to understand and empathize with an other" (Blackburn \& Clark, 2007, p. 19). So while we shared with our participants an interest in - and concern about - the teaching of writing, we consciously took up a stance of "imaginative engagement", a positioning that seeks to be in dialogue with those who speak "from some place other than your own" (Appiah, 2006, p. 85).

\section{Participants}

We were intentional in inviting practitioners who would challenge assumptions we and others might have about the practice and ethics of writing pedagogy, and who might revise and reframe our own ways of thinking about our identities and practices as writing educators.

Invitations to participate in the study were extended to 30 educators known to us through our professional literacy education affiliations as educators who value writing and the teaching of writing. Other criteria for inclusion in the study included representation of the sociocultural and institutional diversity of the province's K-12 schools and other education agencies, and a range in participants' teaching experiences. Thus, the study encompassed the perspectives of practitioners located in a wide sampling of geographical contexts (e.g., urban, rural, suburban, northern, reserve); schools (e.g., French Immersion, independent schools, alternative public schools, and school divisions with marked ideological distinctions in the articulation of their missions); and in organizations offering afterschool and weekend educational programming for youth, adults, and families. The data include practitioners with relatively few and many years of experience, working at all levels (e.g., early years through adult) and in a variety of positions (e.g., classroom teachers, administrators, literacy coaches, resource teachers) within both formal and informal learning institutions.

\section{Data Collection}

The one-hour, semi-structured interviews were scheduled at the participants' convenience, at places of their choosing. All of the interviews were conducted face-toface by at least one of the authors, with the other author joining via Skype when a faceto-face meeting was not feasible. Interviews were audio recorded and transcribed. The interview consisted of four areas of inquiry, detailed in a letter sent to participants ahead of time and reviewed at the beginning of each interview: first, their past and present experiences with writing and with writing education; second, the kinds of writing that constitute their current practice (or the practice of teachers with whom they work); third, 
the changing dynamics (e.g., social, cultural, political, economic, linguistic and technological) at play in the lives of their students and how these dynamics affect their pedagogical decisions as teachers of writing (or of which they are conscious in their support of teachers); and fourth, the professional learning opportunities and support that currently exist for teaching writing, and the kinds of professional support and learning opportunities they felt would be of most value to them. Interviewees were told they could address any and/or all four areas; they were encouraged to use the guide simply as a starting point for sharing what was of most importance to them.

Given our knowledge of the practitioners in this study, we expected that they would choose to view the complexities of their students' lives as central to their pedagogical decision-making, and that the interview data we gathered would align with community-based research focused on issues of "educational justice" (Campano, Ghiso, Yee, \& Pantoja, 2013, p. 314). Indeed, we had anticipated that their self-reflexive explorations as writing educators would reference "the best interests of learning and life chances of students and their communities" (Cochran-Smith \& Lytle, 2009, p. 123). But what we had not imagined was the extent to which our participants would so openly and vulnerably entrust us with their poignant personal and professional stories during the interviews. Thomas King (2003) has boldly asserted: "the truth about stories is that that's all we are" (p. 2). As human beings, as teacher educators, and as researchers who care about our practitioner colleagues, their students, and the quality of writing education in the province, this study brought us into further entanglement with our participants' professional lives and implicated us in their stories. Having truly heard their stories we better understood King's forewarning: "don't say in the years to come that you would have lived your life differently if only you had heard this story" (2003, p. 29). Listening closely in the interviews, for example, to our participants' descriptions of the obstacles and hardships they had encountered as writers and teachers of writing, we became witnesses to their innovative and improvisational moves in the face of ever-changing contingencies of space and place. We heard them repeatedly question their teaching decisions and actions. And we were surprised to observe them imagine, produce, and quite literally "perform" the intricacies, mutability, and plurality of their identities (Holland, Lachicotte, Skinner \& Cain, 2003), as they brought their locally-situated stories to life. During the interviews and in our later reading, rereading, and analysis of the interview transcripts, we vicariously entered their collective "figured" worlds (Holland, Lachicotte, Skinner \& Cain, 2003) and encountered writing and pedagogical spaces we could never otherwise have known. As Goffman's (1959) notion of a "social identity" suggests, it seemed to often be the case that "if enough rapport has been developed between the researcher and participant-actor, the latter will reveal 'backstage' knowledge of him- or herself" (Saldaña, 2013, p. 127).

\section{Data Analysis}

As an intermediate phase of analysis, then, we turned to dramaturgical coding (see, for example, Berg, 2001; Feldman, 1995; Goffman, 1959; Saldaña, 2005, 2011, 2013). Dramaturgical coding applies "the terms of conventions of character, play script, and production analysis to qualitative data" (Saldaña, 2013, p. 123). By "staging" the data, we would need to examine more closely how the participants positioned themselves, how they responded to the conflicts they experienced as teachers, and how they used 
language and discourse for that work. Dramaturgical coding also seemed to provide a flexible set of tools for representing the dynamic, ongoing nature of participants' experiences as educators. For teaching, like culture, is "an ongoing performance, not a noun, a product, or a static thing. [It] is an unfolding production, thereby placing performances and their representations at the center of lived experience" (Denzin, 2003a, p. 328).

From Saldaña (2013) we began with codes for character (see Table 1, above the triple-line), highlighting and annotating the transcripts digitally using a PDF reader. In the process of coding, we added to the definitions suggested by Saldaña (see Table 1, in italics) and developed new codes (see Table 1, below the triple-line) to better reflect the research questions and data. (Note: We also found one of Saldaña's suggested codes ("Attitudes") to be not as useful for our purposes, as attitudes were often implicitly revealed in participants' discussion of "Conflicts", "Objectives", and "Tactics." We subsequently deleted it from our code sheet.)

Table 1

Dramaturgical Codes

\begin{tabular}{|c|c|c|c|}
\hline $\begin{array}{l}\begin{array}{l}\text { Codes } \\
\text { (colours) }\end{array} \\
\end{array}$ & Terms & Definitions & Example \\
\hline $\begin{array}{l}\text { OBJ } \\
\text { (purple) }\end{array}$ & $\begin{array}{l}\text { Participant- } \\
\text { Actor } \\
\text { Objectives }\end{array}$ & $\begin{array}{l}\text { Motives in the form of action } \\
\text { verbs; often expressed as } \\
\text { objectives related to teaching, } \\
\text { students' learning, the role } \\
\text { writing should/could play }\end{array}$ & $\begin{array}{l}\text { "So I want them to learn } \\
\text { about the Civil Rights } \\
\text { movement and Idle No } \\
\text { More and things that are } \\
\text { happening in the news and } \\
\text { have some historical } \\
\text { context." }\end{array}$ \\
\hline $\begin{array}{l}\text { CON } \\
\text { (yellow) }\end{array}$ & Conflicts & $\begin{array}{l}\text { Obstacles confronted by the } \\
\text { Participant-Actor which } \\
\text { prevent him or her from } \\
\text { achieving his or her } \\
\text { objectives; conflicts stemming } \\
\text { from larger systemic issues }\end{array}$ & $\begin{array}{l}\text { "They had no patience for } \\
\text { writing, and they hated } \\
\text { it.... any time you asked } \\
\text { them to pick up a pencil it } \\
\text { was like a declaration of } \\
\text { war I was making." }\end{array}$ \\
\hline $\begin{array}{l}\text { TAC } \\
\text { (green) }\end{array}$ & $\begin{array}{l}\text { Participant- } \\
\text { Actor Tactics }\end{array}$ & $\begin{array}{l}\text { Strategies used to deal with } \\
\text { conflicts or obstacles and to } \\
\text { achieve his or her objectives; } \\
\text { descriptions of responsive } \\
\text { classroom practice }\end{array}$ & $\begin{array}{l}\text { "So what I did was I } \\
\text { started with, 'What do } \\
\text { students need to be able to } \\
\text { write?"” }\end{array}$ \\
\hline $\begin{array}{l}\text { EMO } \\
\text { (magenta) }\end{array}$ & Emotions & $\begin{array}{l}\text { Experienced by the } \\
\text { Participant-Actor }\end{array}$ & $\begin{array}{l}\text { "I'm excited about it; I } \\
\text { hope we get it." }\end{array}$ \\
\hline
\end{tabular}




\begin{tabular}{|c|c|c|c|}
\hline SUB (pink) & Subtexts & $\begin{array}{l}\text { The Participant-Actor's } \\
\text { unspoken thoughts or } \\
\text { impression management, in } \\
\text { the form of gerunds; 'tip-of- } \\
\text { the-iceberg' comments, where } \\
\text { audiences' understandings of } \\
\text { larger issues and/or contested } \\
\text { practices may be evoked }\end{array}$ & $\begin{array}{l}\text { "Survival for them ... is } \\
\text { the more important thing." }\end{array}$ \\
\hline $\begin{array}{l}\text { ID [SUB] } \\
\text { (turquoise) }\end{array}$ & $\begin{array}{l}\text { Identity/ } \\
\text { Subjectivities }\end{array}$ & $\begin{array}{l}\text { The Participant-Actor's } \\
\text { identity/subjectivities as a } \\
\text { teacher, writer; influences, } \\
\text { processes of becoming and } \\
\text { learning how to teach; } \\
\text { characterization }\end{array}$ & $\begin{array}{l}\text { "I'm much more } \\
\text { connected with art } \\
\text { teachers ... less connected } \\
\text { with English teachers." }\end{array}$ \\
\hline $\begin{array}{l}\text { SET } \\
\text { (orange) }\end{array}$ & Setting & $\begin{array}{l}\text { The settings or contexts } \\
\text { referred to by the Participant- } \\
\text { Actor; descriptions of places, } \\
\text { people }\end{array}$ & $\begin{array}{l}\text { "And that's our school, } \\
\text { very transient, very } \\
\text { international school ... a } \\
\text { lot of different } \\
\text { backgrounds." }\end{array}$ \\
\hline $\mathrm{REF}$ (red) & Reflections & $\begin{array}{l}\text { Spoken like soliloquies that } \\
\text { reflect insights into teaching, } \\
\text { literacy, language, students, } \\
\text { conflicts and tactics; visions } \\
\text { for the future }\end{array}$ & $\begin{array}{l}\text { "And after thinking about } \\
\text { writing for years and years } \\
\text { and watching children and } \\
\text { I've had children who-- } \\
\text { my one little boy right } \\
\text { now, who right now he's } \\
\text { expressing himself } \\
\text { completely through, like } \\
\text { it's all pictures ..." }\end{array}$ \\
\hline $\begin{array}{l}\text { INP } \\
\text { (underline) }\end{array}$ & $\begin{array}{l}\text { Influential } \\
\text { People }\end{array}$ & $\begin{array}{l}\text { Other "characters" who are } \\
\text { referenced as playing a role in } \\
\text { becoming/being a writer, } \\
\text { teacher }\end{array}$ & $\begin{array}{l}\text { "the Grade }[\mathrm{x}] \text { teacher"; } \\
\text { "key people like [name]"; } \\
\text { "the children are the } \\
\text { ones"; "expert teachers"; } \\
\text { "three teachers" }\end{array}$ \\
\hline
\end{tabular}

The analysis was supported through memo-writing, with methodological and conceptual memos written for each interview (Corbin \& Strauss, 2008). Coding and analyzing the data in this way allowed us to see more clearly "the qualities, perspectives, and drives of the participant[s]. It also provide[d] a deep understanding of how humans in social action, reaction, and interaction interpret and manage conflict" (Saldaña, 2013, p. 124). By highlighting (in yellow) the conflicts practitioners articulated, we could see the ways these conflicts often worked as plot lines throughout the script. As we shall attempt to demonstrate, the conflicts practitioners articulated are complex, embedded in 
economic, political, and institutional structures and systems that perpetuate inequity and injustice. With their words, they staged for us the realities of those conflicts in their lives and the lives of their students. Using this process of analysis helped us to move the research forward, closer to social action.

It also helped us to more fully appreciate the ways practitioners were responding to such conflicts. The colours artfully rendered the interview transcripts, allowing us to note the predominant hues of individual interviews at a glance. For example, when we noted that an interview had green (TAC) following almost every instance of yellow $(\mathrm{CON})$, we were struck by the ways a practitioner was positioning her practice to respond to the conflicts her students were experiencing (conflicts symptomatic of much deeper, systemic issues). When a coded transcript included several pages that were predominantly highlighted in red (REF), we were drawn to look again, for instance, at the reflexivity articulated by a practitioner from her unique social location. In those "soliloquies", we heard voiced the powerful localizing of theory that reminded us of the insider knowledge of practitioners. But we also witnessed their doubts, questions and concerns, anger, frustration and despair.

While contributing to the surfacing of the conflicts and tensions they faced in their work, the strategies and tactics they took up in their practice, their objectives for their students and themselves, and, to a lesser degree, the emotions and subtexts of this work, the character codes we began with did not fully capture the identity work (or "characterization") that participants were doing in talking about their identities as writers, teachers, and teachers of writing. Most likely because it was the first area of inquiry of the four we provided, almost all the interviewees "set the stage" by sharing their own encounters with writing (or lack thereof) in school and outside of school. We developed the "ID" code to be able to look more closely at the influential people, experiences, practices, spaces, and material aspects - both past and present - that practitioners in the study referenced as contributing to their identities as writers and teachers of writing.

Through the interviews, we were also often introduced to teachers, professors, parents, family members, colleagues, writers/authors, and others who shaped the writing and teaching identities of those we interviewed. The code "INP" was created to index those and the many other "characters" who played various roles in the participants" responses. This drew our attention to the fact that the "cast" for some practitioners was quite vast, including a host of mentors that these practitioners attributed to having influenced their thinking and practice throughout their careers. For others, the cast was much smaller, and/or these practitioners shared how their access to colleagues and mentors had been limited by career changes, programmatic and fiscal priority shifts, or other factors. Another interesting pattern was the coding of students as influential people. As one practitioner reflected: "and then the children, they teach you so many things.... The fundamental ideas of my workshop were still there but the students every year are the ones that change it."

Relatedly, the code "SET" was added in response to participants' descriptions of the contexts they referenced-mostly in regard to the particular sociocultural demographics or institutional practices in which they work. These references locate the scripts within their local contexts, set against backdrops that show stark socioeconomic and sociocultural differences, or in some cases are eerily similar, even though they are 
geographically far apart. But they also reflect and are shaped by global forces: war and displacement, poverty, globalization and im/migration.

\section{Research-Based Theatre}

The dramaturgical coding of the data provoked us to consider how analysis and interpretation rely on more than linguistic modes - i.e., more than the words left on the page. In our memos we began playing with ideas for "staging" the scripts, writing in suggestions for stage directions that pushed us to capture and interpret the emotional, embodied nature of participants' narratives and to consider how to creatively use facial expressions, gestures, and body movements to communicate the power of their stories to others. For example, how might we imagine the positioning of the "participant-actor" in relationship to another character during a dialogue that was related in the script? How might we stage a scene that allows the "audience" to see the unfolding of events as they occurred inside the practitioner's classroom? From where on the stage (e.g., front and centre?) and how (e.g., in a whisper?) should a "participant-actor" engage the audience in her "soliloquy" on commercial reading programs? Thus, the analysis provoked an extension of our researcher role to what Saldaña (2013) terms the "researcher/ethnodramatist" in order to envision "a participant-actor's performance" ( $p$. 126).

Arts-based research approaches, including research-based theatre, offer researchers a mode for research writing that conveys the stories and insights gained through research via compelling performance texts (Beck, Belliveau, Lea \& Wager, 2011; Denzin, 2003b; Mackenzie \& Belliveau, 2011). Research-based theatre offers researchers and readers/audiences a platform for noticing and helping to name how the individual relates to a collective, within the larger enterprise of engaging in the arts as a vehicle for moving towards more democratic education and social justice. It also serves as a means for researchers to explore the experiences of those we wish to better understand "in a way that [does] not lead to the reproduction of the policies and practices of colonialism, linguistic discrimination, and racism" that we intend to challenge (Goldstein, 2008, p. 87). Goldstein (2008) argues that playwriting affords important possibilities for researchers: first, as a mode by which "to challenge the "ethnographic authority' (Clifford, 1983; Lather, 1993) of their own writing" and second, by discouraging "the fixed, unchanging ethnographic representations of research subjects" which negatively construct the "Other" (p. 87). In performances of ethnographic plays, Goldstein (2008) suggests that opportunities are created for "Other actors [to] ... enact and enlarge the identities of the characters that have been created"; for research participants and other audiences to "ratify or critique [a play's] analysis"; for researchers to evaluate "how their own biases may dominate the text"; and finally, for reaching broader audiences and encouraging "public reflexive insight" into the experiences presented (p. 87-88).

Research-based theatre encompasses a full spectrum of approaches that have been helpfully defined by Beck, Belliveau, Lea and Wager (2011) on two intersecting continua: i) a continuum of research and inquiry methods, and ii) a continuum of performance that considers the various audiences, purposes, and types of staged performances. The research continuum ranges from formal systematic research to more informal research processes, which draw upon intimate first-hand accounts (e.g., 
autobiographical writing, letters and journal entries), or still rich but more distant secondhand accounts (e.g., biographies and reporting in media), or less systematic inquiries based on widely known historical facts (Beck et al., 2011, pp. 690-691). The related performance continuum ranges from performances designed for restricted and specific audiences (e.g., a workshop for the research participants themselves, or a particular professional conference audience), with less emphasis on theatrical conventions and aesthetic qualities, to more open performances designed for wider audiences (from stakeholders to general audience members) and with much greater attention paid to aesthetic merits and theatrical richness (Beck et al., 2011, pp. 692-694).

With a wide range of local experiences represented in the stories told by our interview participants, research-based theatre invited us to consider how we could both honour and mediate the pluralities of this experience by moving across spaces and opening up opportunities to observe and imaginatively step into the roles of others in the play. This made it possible to not only "represent the performance of subjectivity" so palpable in our participants' interviews, but through the process of selecting and arranging individual performances we were able to surface the social critique of "dominant cultural paradigms from the perspective of personal memories and cultural histories" (Garoian, 1999, p. 8) that ran so deeply through our data.

For us, the writing of the dramatic scripts was very specific, with an intention to create a "text-centered performance" (Beck, Belliveau, Lea \& Wager, 2011). The audiences we imagined were those who might attend academic and professional conferences and workshops, including other literacy researchers, university faculty, K-12 educators, teacher candidates, and the participants themselves. We had in mind the limited staging such conferences and workshops would allow; we were also aware of the time and presentational constraints of such venues. Thus our goal was to stage the research texts presentationally, portraying participants' stories and experiences in their own words to create a space that - while not engaging the audience in a creative or participatory drama-would allow for readers and viewers "to recover [and] yet interrogate the meaning of lived experience" (Denzin, 1997, p. 94-95).

This process called for an imaginative shift in mediating the data, moving language back into - and inviting new ways to represent-its physical, embodied, kinaesthetic, and auditory power. Here, our respective experiences with process-based drama, Reader's Theatre, school drama and public speaking clubs, and prior arts-based research were fruitful resources. Aware that we planned to both perform the texts on stage as well as to share them with audiences on the page, we edited, wove together, and rearranged participants' words in order to enhance their "structure and flow" and embed "appropriate physical and vocal action through italicized stage directions" (Saldaña, 2013, p. 126). As indicated in the two performative texts in this paper, we made only very small changes to the words of the participants, showing those with ellipses (where we have omitted words and sentences) and brackets (to indicate small changes to words or words inserted for clarity that were not in the original text). This process necessitated identifying, interpreting, and then generating possibilities for staging the scripts in ways that would confront and invite us again as an audience to witness the position and relationship of the speaker to us and our experiences, to sources of conflict, to students, and to others. We sought through their performance and publication to heed Denzin's 
(2003b) call for performative texts to "be more than cathartic, [they] must be political, moving people to action and reflection" (Denzin, 2003b, p. 470).

\section{Reader's Theatre (RT): "Learning to Teach Writing”}

The four readers stand in various poses across the stage, some distance apart, with their backs to the audience. When they speak, they turn to face the audience and take a step downstage. When they finish speaking, they turn around, with their backs again to the audience.

Reader 1 (leans in, confiding):

I'm still learning to be an English teacher.

The first thing I did (gestures as if to invite someone to come onstage) was invite the English consultant in just to make sure I was on the right track (nods, smiles, waves "thank you"). The next thing I did (using arms to pantomime a flurry of action) was start throwing out course material from the filing cabinet that had a lot of blanks to fill in.

Reader 2 (points to herself):

I didn't have anyone (looking around her) to influence my thinking of how to be a writing teacher or how to teach reading for that matter either. That [visit] was the best thing I had ever done; it opened my eyes to so many ways to look at children (as if watching children). At that point I realized (excitedly), "Yes! Look what kids can do! It's incredible!" And it's there in the child; it's no magic. (more softly) Well, the teacher, yes, (pause) there is some sprinkling of magic in the sense of what you do to bring that out of them.

Reader 3 (faces the audience, but with body turned slightly sideways; smiles nostalgically, pantomimes standing at a counter, stirring something in a bowl):

Some of the greatest teaching I got was from my daughter who learned to read by writing She would sit at the typewriter in the kitchen while I was trying to do things and say, (stops stirring and in the voice of a younger child) "How do you spell 'the'? How do you spell 'dog'? How do you spell 'was'?

Because she had stories she wanted to tell

She wanted to communicate

And it was because she wanted to communicate that she learned to write 
Reader 4 (looks around and then moves downstage centre, addressing the audience in confidential tones):

They really sent a strong message [about] what their expectations are for reading ... (imitating an authoritative voice) "This is what you do (using index finger to jab); this (jabs again) is it." (taking up confidential tone once again) And I know that writing's coming next.... I can feel it in our school ... what they're saying ... [about] assessments and calling everybody " $F$ " readers or " $G$ " readers or whatever it is. The next question that they're coming to is writing. And they're looking at (imitating louder authoritative voice), "What are we going to do, what canned boxed thing is out there that we can give teachers so they know what to do with writing?"

(Confiding) I'm watching [my] colleagues; they're using story starters.

We've got a center set up and so the writing part for them is giving story starters And then the kids would pick a story starter and that's what they would do for their writing.

(Leaning in to audience) I don't do the story starter because in watching children, they can start their own story.

They don't need me to start it.

And the ones who sit there and have to think-because there's some that need to really, really think and process it ... before anything gets put on the page

But they have - the story; [it]'s there, it's in them

But sometimes it's a conversation with me

or that think time that [they need before] it's going to come

And I don't think it's coming from the story starter or me saying,

"Tell me a story about a penguin," because they're not invested in it at their best.

Like I mean (again, leaning forward), the writing that we're having right now ...

the voice already present in their writing is incredible and they're just driven right now. (Pauses. Looks around.) Nobody comes in my room ... they think it's OK. Right.

I'm blessed that way I guess. They stay out of my room.

(Pauses.) ... If they came in, am I doing what I'm in their eyes for reading supposed to be doing? Yes and no....

(Again, appealing to the audience in confidential tones) I'm afraid that's what's coming next for writing and ... they're looking for that, and that's that pressure that I feel.

\section{Reader 1 (gestures to the other Readers):}

I think for teachers, having writing workshops for themselvesto $d o$ the writing or the story-telling ...

I think when you actually have to write a poem ... or piece yourself then you realize how terrifying a blank page can be....

... How are you going to make that safe for your students?

What were the pitfalls? What were your distractions? How did you handle that? 


\section{Reader 2 (Nods to audience):}

Having a team is huge because you need that person to talk to, and I don't have that right now.

I went to [a conference] and ... I bought some new books there, but who am I going to talk [to] about that? (Shrugs, looks around, shakes head.) Nobody.

I can read the book but ... they're not those "canned" things.

You can't read it and then they're saying what to do.

You're thinking about it (pause) and then you think about it with your kids (pause) and then you fumble around with it all, (looking back at other readers, then at audience) but it's nice to fumble with somebody else, and think about it [together].

Reader 1 (as an aside):

A really valuable thing is to bring in

flesh and blood authors, storytellers and poets

I've learned a lot from that ... (pause)

[A poet] came in (with humour) ... and she asked them if they had an English teacher who was killing their love of poetry ...

(gives the audience a guilty look)

[So] I took all the teaching that I do about metaphors and irony and things

And I put it into my advertising unit ... (pause)

If they learn to hate ads, it's OK.

Reader 4 (walks downstage, thoughtfully nodding and reminiscing):

I had [an "expert" teacher come from another school] — she came way back when I was sitting and thinking about all this writing.

She came to my classroom. And sat — and didn't know my kids—but she sat and sort of watched for a while, and stepped in and did a writing lesson with them and then she was back a second day and I was doing it and she was with me And oh, you know (pause); those are things ... (nostalgically, but also emphatically) those were powerful situations where

you had somebody who's an expert teacher or writer with you in the classroom.

Reader 3 (looks around, and then in a stage whisper, confesses):

I feel really isolated.

(A little louder) There's nobody to talk to about writing.

(With a touch of irony) I talk about reading.

Because we're a school in believing that you're an " $\mathrm{M}$ " reader ... and ... (whispers again) it's frustrating me. 
(A little louder, looking left centre, as if at a display) And they want to put a data board up with names of people [so] that they know that these people are "M's" and these people are "Ns"

and I feel so-(draws body in, looks constrained, takes a step backwards)

like I'm thinking (frowning, looking expectantly, from one side to the other)

somebody else must be thinking, "Why?"

(Louder) There's gotta be somebody else sitting there

(looking around more desperately) — when they're sitting at that ... meeting

thinking, "Why?"

(Louder) I can't be the only one. ...I'm not! I can't be!

Reader 2 (gestures to all the Readers on stage):

How do you pull people together so that they can write and speak out together and act out together and make more space for other people

who either maybe don't see it yet

or are afraid ...

Reader 1 (speaks regretfully):

I had said some things to [someone in the division].

He's not happy with me.

He made sure he knew who I was ...

- that wasn't good.

I should have kept my mouth shut.

Reader 2 (nods to Reader 1 and the audience):

... there's lots of good reasons to be afraid.

Reader 3 (gestures to all the readers):

Your job, your regulatory job, your legal job, your policy job

is to maintain an equilibrium (walks as if on a tightrope to center stage)

and art destabilizes.

(Readers wobble in their places, looking like they are about to fall over. They "freeze" in position. Reader 3 loses balance on the "tightrope" and momentarily also "freezes."

Regaining balance, Reader 3 then walks to each Reader and with a tap (like in a game of Freeze Tag), "unfreezes" them. Readers smile, stand upright, look around, see one another, and form a tight circle on stage right.)

So people need spaces outside of hierarchies (walking over to the circle that has formed) so that they prepare privately with people who are safe (Readers pantomime listening to one another, nodding, then linking arms.)

So they can go public (Readers open the circle and walk towards centre stage) with these odd things that other people might be afraid of or dislike or are annoyed with-all those things.

It's about taking care of each other (they gesture for Reader 3 to join them and link arms) 
and preparing each other to go in some unfriendly places (Together, Readers move turn and walk up stage).

\section{Multi-Voiced Monologue (MVM): "Designing Critical Pedagogies of Writing"}

This monologue merges the voices of multiple participants. To stage the monologue, five "voices" line up in single file, one after the other, from downstage centre to upstage centre. This has the effect of looking like one actor. Each voice will perform one stanza, with the first voice reading the first stanza, after which, the "voice" will move to the back of the line and the next in line will resume the monologue.

And every fall we have been going to the Petroforms

It's interesting to explain to them that this is a text

These rocks tell a story and have meaning in them

You might not know this if you just quickly walk through

But we have someone to guide us and talk about

"OK this is a turtle, but what does the turtle mean?

Did you know that you're standing on the turtle's back?"

Once you start hearing someone tell you the story

It's a different experience

A text isn't just a boring book on a shelf

You can read all kinds of things

I did an art show once with students ...

I had a photography club and I had them go out and take pictures in their neighbourhood ... And one of my favourite, favourite photographs was this really tough looking guy-I mean, he was so obviously gang, and if I saw him on the street,

I'd probably be concerned

And it said, "My Brother"

And I thought (snaps fingers), "That's it."

That's just turning things on their head and giving students perspective of what this was that we were looking at. And that's what we needed to see.

A lot of the students I teach here just don't have a lot of words

They don't have a lot of words in any language

And what language they have is imperative language

Where people have told them to

"Be quiet. Sit down. Do this."

And there isn't much storytelling around that.

So I want them to learn about the civil rights movement

And Idle No More

What ... makes sense to students, if we talk about civil rights

Is to start with residential schools

A lot of them turn to me and they say

"Well, that explains a lot!"

And suddenly things begin to make sense in their own family:

You know, why this person won't talk about this;

Why so and so is an alcoholic; 
Why they see people in the street.

Well there's a reason to all of [it]-

There's a history to all of this.

It fills in that piece of meaning

About why things are the way they are.

I think art at its root is political.

Its essence is political.

So when you make art with people,

whether it is in theatre or writing or in music ...

At its essence it destabilizes what we consider to be normal, acceptable,

all of those things, right? So it really troubles it in a really beautiful way....

So that is where we're taking thinking about ourselves as communicators ...

how do we invite people into a space and get them to think about themselves

as writers, as thinkers, as artists?

Because I think that is a very powerful way to conceive of yourself,

as opposed to what one of the children said the other day which is,

"This school is always going to see me as a Goddamn refugee."

When you write and think artistically there is a different identity marker there for you.

\section{Discussion}

The performative pieces highlight the ways educators theorize writing and the teaching of writing from their local experiences, suggesting how they understand and situate their subjectivities and pedagogies as writing teachers in relationship to their own backgrounds, the dynamic and diverse contexts in which they teach, and their students' knowledge and literacy practices. They also suggest the tensions educators sometimes experience when the theories and pedagogies that emerge from their work with students in their classrooms are at odds with those being imposed from other places and spaces. In this section we revisit our research questions in relationship to key dramaturgical codes, exploring the local knowledge of practice about writing and the teaching of writing particular to these teachers' experiences, which will inform local action in developing a critical writing network with and for practitioners.

\section{Objectives}

Instead of allowing others to identify their teaching and learning objectives, we see in this study the ways teachers are articulating their own objectives for their students. In the Multi-Voiced Monologue (MVM), we see how a teacher uses the Petroforms to expand students' understandings of a text, but also to situate literacy in and through their cultural connections to place. Reader 1 (RT) described (more fully in the interview) how, in a new school with a very specialized population, she initiated a creative, critical curriculum that drew on students' cultural and gendered identities, and threw out all the old course materials "that had a lot of blanks to fill in." Reader 2 (RT) talks about the ways she had learned "to look at children", allowing her writing pedagogy to emerge from her desire to enable her students to tell the stories they want to tell. She articulates how her belief that students can "start their own story" puts her theoretically and pedagogically at odds with her colleagues, who, rather than design story-writing 
curriculum and pedagogy around their students, initiate storytelling from pre-established story starters.

\section{Identity/Subjectivities}

The vignettes speak to the importance of teachers establishing identities as writers. Reader 1 (RT) insists that teachers need to experience the vulnerabilities of being a writer (e.g., "how terrifying a blank page can be") in order to anticipate what their student writers will face and help them negotiate their own identities as writers.

\section{Influential People}

The vignettes illustrate the relational nature of teaching. Teachers mentioned by name those who had influenced their thinking and practice. These included "immediate" mentors - those in their own schools who shared ideas around the photocopier, met over lunch or after school, and were willing to observe and be observed in the classroom. They also included "local" colleagues - those beyond their schools with whom they engaged professionally through study groups, organizations, or as former colleagues. They included "expert" practitioners whose books, presentations, workshops, residencies and courses had profoundly shaped their teaching. And, for many, the "casts" of influential people featured their students, who taught them powerful things about language, literacy, and social justice - "turning things on their head" in order to see "what we needed to see."

\section{Conflicts}

Another aspect of a relational understanding of teaching writing was evident in the isolation practitioners felt. Some were isolated geographically, some philosophically. Others were isolated by nature of their context or role (e.g., small school, only educator in their position), some by what they believed they lacked in their background or professional training, some by the design of their space (e.g., the location of their classroom in a building), others by their philosophical orientations. The isolation was particularly powerful for those who had, at other times in their careers, thrived in their collegial, collaborative environments. They commented on "missing it", of feeling "alone". They spoke desperately of the need to talk with others, to share their thinking, to confide in those who were engaged in similar kinds of work about their questions and concerns. Others voiced their vulnerabilities - questioning their capacity to grow as an educator or to continue to teach in ways they felt put them at risk without a support system.

\section{Settings}

Another aspect of the relational that is perhaps more nuanced is the work of relating the teaching of writing to larger issues of students' social locations. The vignettes speak of teaching and writing as connected to voice, social change, equity, and transformation. One teacher explained how she connected her teaching of the Civil Rights and Idle No More movements by beginning with understanding residential schools, to "fill in that piece of meaning about why things are the way they are" (MVM). Others spoke passionately about inviting people "to think about themselves as writers, as 
thinkers, as artists" through developing their capacity for words beyond "imperative language" and their identities as more than "Goddamn refugees" (MVM).

\section{Subtexts}

The vignettes portray the pressures that educators said they faced in the palpable, visible drive to improve reading achievement. "I can feel it in our school," Reader 4 explained, "what they're saying ... [about] assessments and calling everybody " $F$ " readers or "G" readers". Reader 3 spoke of the "data board" displayed so everyone would know which readers were "M's" and "N's." Commercial assessments and products were realized as contributing to an insidious, ubiquitous subtext that essentialized students and learning; teachers warned that writing would be next.

\section{Tactics}

In response, educators shared their tactics for teaching writing, for example, by keeping quiet about what they were doing in their classrooms. As Reader 4 (RT) suggests, teaching in contentious spaces is about finding an ethical balance between commitments to her students and to her administration. "Am I doing what I'm in their eyes ... supposed to be doing? Yes and no...." In a less grave but similar vein, Reader 1 (RT) describes her confrontation with a poet who suggested she might be killing students' love of poetry by teaching "metaphor and irony and things." Obliged to teach literary terms, she responded humorously by shifting them to her advertising unit, saying, "if they learn to hate ads, it's OK."

\section{Emotions}

The dramatic vignettes convey a variety of emotions: wonder, joy, frustration and fear. Reader 1 (RT) conveys the isolation she feels at a meeting when she is the only one who speaks in opposition to an initiative. "Somebody else must be thinking, 'Why?' I can't be the only one." Reader 2 (RT) identifies how teachers are working in the face of authority that threatens what teachers know is best for students. As Reader 1 (RT) describes, there is a fear of the repercussions of speaking to power. For these educators this is an ethical tension: while teaching behind closed doors doesn't change policy, it does mean a greater chance of survival. This is the equilibrium Reader 3 addresses, but it is an exhausting equilibrium to maintain; it is not satisfying, and it becomes increasingly difficult when educators push themselves and their students to engage in curriculum that matters (Christensen, 2009) and by its very nature "destabilizes" hierarchies of power.

\section{Reflexivity}

Thus, the vignettes speak to the reflexive subjectivity work teachers are engaged in. Thinking about their identities in relationship to writing and critical writing pedagogies demands critical reflexivity about themselves, their students, and their teaching. We see the tensions that emerge from the "discrepancies between what is intended and what occurs" and the critical questions that "emanate from neither theory nor practice alone but from critical reflection on the intersections of the two" (CochranSmith \& Lytle, 2009, p. 42). Such reflexivity demands educators take an inquiry stance (Cochran-Smith \& Lytle, 2009) that grows from a long-term commitment to one's students and professional growth as a teacher. 


\section{Implications}

The study was also intended to inform our efforts to create a sustainable professional learning network in critical writing pedagogies. As we move forward in that work, several important implications need to be considered: First, we need safe spaces "outside of hierarchies" for this work, or in other words, more backstage rehearsals "to prepare each other" to "go public" (Reader 3, RT). An unanticipated benefit of the study for many participants was the space and time they said it afforded to talk about their students and classrooms. The constraints of school days, classes, courses, meetings, and other pressures that typically limit such conversations were abated, even if just for an hour. As the stage directions attempted to indicate, there is strength in being part of a group and in having others "tak[e] care of each other."

Second, we need to recognize we are pushing against individualistic and instrumentalist ontologies that suggest that students (and teachers) need to be fixed, that there is a program for that, and that any problems that arise can and should be solved on our own. Reader 2 (RT) reminds us that "knowledge" is so often passed down to teachers; that teachers are not expected to produce this knowledge on their own. He describes how the professional reading he is doing is not of the "canned" variety that tells him "what to do"; instead, he has selected books that require "thinking about it" from the location of the classroom, with his students, and being willing to "fumble around with it all." But he suggests how "it's nice to fumble with somebody else, and think about it" together. This points to the collective work of inquiry; the active production of knowledge from the location of practice that is necessary to cultivate and sustain critical writing pedagogies not just in one site, but across a province.

Third, we need to create stages that move across boundaries and borders and that invite difference. One limitation of the study is that up to this point, the educators we have interviewed have had reputations as strong writing practitioners. How do we initiate the conversation with others? What happens to "safe" spaces when they are challenged by other sets of assumptions about students, writing, and curriculum? How do we continue to make room on the stage to understand teachers and stories in new ways?

Fourth, we need to acknowledge that the critical work of creating coalitions with teachers around critical writing pedagogies has just begun. We have had several opportunities to perform these dramatic vignettes, each time with a different purpose and audience. We have noted how the performative mode has contributed to making the research both engaging and more accessible to a broader audience, from teacher candidates to policy makers to potential partners. We have, in these performances, been able to communicate different themes: for teacher candidates we have emphasized the agency and resilience of teachers whose pedagogies of hope (Freire, 1994) are inspired by their care for their students. For policy makers, we have highlighted the power of local knowledge in the diversity of contexts in which educators are working, as well as the themes that cross the local to suggest significant fronts on which to engage educators in critical conversation about curriculum and pedagogy. With potential partners, we have foregrounded educators' creative and critical commitments to educating for social justice and human rights. For us, the performative nature of these texts invite constant attention and revision to the dynamic and changing nature of writing and writing pedagogy and the coalitional partnerships we are creating. We know that critical "ally work" becomes dangerous if we consider it something we can achieve, and a project like this is 
"dangerous" [if] people ... just talk about writing" (Participant). We need to constantly be present in this work ourselves, to articulate our own theories, to examine our own pedagogies, and to engage in collaborative inquiry with others. We need to, as one of the participants put it, "insert [ourselves] in the play."

\section{Conclusion}

Critical pedagogies call for action, but they also call for imagination. As Appadurai (1996) reminds us, it is "the imagination, especially when collective, that can become the fuel for action" (p. 7). In the provincial writing project we are co-constructing with practitioners and our partners, we are beginning to see the action that has been generated through the inquiries and writing of teachers and students about issues that matter - an ecocentric ethic and efforts to mitigate the current and looming ecological crisis; relationships between culture, privilege and pedagogy; "standing up" for plurality of gender and sexual identity and for making schools safe; the interdependence of home and school languages and cultures; exploring challenges to equity, identity, and citizenship in the context of new digital and social media and popular culture; and so on. Working artistically as researchers, we have interwoven performance texts that bring vivid and memorable characters, struggles, pedagogical moments, and often internal or private dialogue into public view, while not compromising the ethical integrity of our research participants in a sparsely populated province. But, research-based theatre demands performance and audiences, where the invitation can be extended to take an imaginative leap and explore "different ways of understanding and seeing the research" (Mackenzie \& Belliveau, 2011, p. 18). It brings together lenses of intellect, aesthetics and empathy. Staging these important stories of writing and writing pedagogy has deepened our belief in the power and potential of the imaginations of teachers and students, researchers, readers and audience members to inspire creative change: "[We] should write. [We] should make a play. [We] should paint the picture" (Participant).

\section{References}

Appadurai, A. (1996). Modernity at large: Cultural dimensions of globalization. Minneapolis, MN: University of Minnesota Press.

Appiah, K. (2006). Cosmopolitanism: Ethics in a world of strangers. New York: W. W. Norton \& Company, Inc.

Beck, J., Belliveau, G., Lea, G., \& Wager, A. (2011). Delineating a spectrum of researchbased theatre. Qualitative Inquiry, 17(8), p. 687-700.

Berg, B. L. (2001). Qualitative research methods for the social sciences ( $4^{\text {th }} \mathrm{ed}$.). Boston: Allyn and Bacon.

Blackburn, M., \& Clark, C. (2007). Bridging the local/global divide: Theorizing connections between global issues and local action. In M. Blackburn \& C. Clark (Eds.), Literacy research for political action and social change (pp. 9-28). New York: Peter Lang.

Campano, G., Ghiso, M., Yee, M., \& Pantoja, A. (2013). Toward community research and coalitional literacy practices for educational justice. Language Arts, 90(5), 314-326.

Chambers, C. M., Hasebe-Ludt, E., Leggo, C., Sinner, A. (2012). A heart of wisdom: Life 
writing as empathetic inquiry. New York: Peter Lang.

Christensen, L. (2009). Teaching for joy and justice. Milwaukee, WI: Rethinking Schools, Ltd.

Clifford, J. (1983). On ethnographic authority. Representations, 1, 118-146.

Cochran-Smith, M. \& Lytle, S. (1993). Inside/outside: Teacher research and knowledge. New York: Teachers College Press.

Cochran-Smith, M., \& Lytle, S. (1999). The teacher research movement: A decade later. Educational Researcher, 28(7), 15-25.

Cochran-Smith, M., \& Lytle, S. (2009). Inquiry as stance: Practitioner research for the next generation. New York: Teachers College Press.

Corbin, J., \& Strauss, A. (2008). Basics of qualitative research: Techniques and procedures for developing grounded theory ( $3^{\text {rd }}$ ed.). Thousand Oaks, CA: Sage.

Denzin, N. (1997). Interpretive ethnography: Ethnographic practices for the $21^{\text {st }}$ century. London: Sage.

Denzin, N. (2003a). Performance ethnography: Critical pedagogy and the politics of culture. Thousand Oaks, CA: Sage.

Denzin, N. (2003b). The practices and politics of interpretation. In N. Denzin \& Y. Lincoln (Eds.), Collecting and interpreting qualitative materials. (2nd ed.). Thousand Oaks, CA: Sage.

Feldman, M. S. (1995). Strategies for interpreting qualitative data. Thousand Oaks, CA: Sage.

Fine, M. (2001). Forward. In B. Kamler, Relocating the personal: A critical writing pedagogy. Albany, NY: SUNY Press.

Flint, A. S., \& Laman, T. T. (2014). Where poems hide: Finding reflective, critical spaces inside writing workshop. In J. Zacher Pandya \& J. Ávila(Eds.), Moving critical literacies forward: A new look at praxis across contexts (71-82). New York: Routledge.

Freire, P. (1970/2000). Pedagogy of the oppressed. Bloomsbury Academic, $30^{\text {th }}$ ed.

Freire, P. (1994). Pedagogy of hope: Reliving pedagogy of the oppressed. London: Continuum.

Garoian, C. R. (1999). Performing pedagogy: Towards an art of politics. Albany, NY: SUNY Press.

Gee, J. P. (1990). Social linguistics and literacies: Ideology in discourses. New York: Routledge.

Goffman, E. (1959). The presentation of self in everyday life. New York: Anchor Books.

Goldstein, T. (2008) Performed ethnography: Possibilities, multiple commitments, and the pursuit of rigour. In K. Gallagher (Ed.), The methodological dilemma: Critical, creative, and post-positivist approaches to qualitative research (pp. 85-102). New York: Routledge.

Hasebe-Ludt, E., Chambers, C. M., \& Leggo, C. (2009). Life writing and literary métissage as an ethos for our times. New York: Peter Lang.

Holland, D., Lachicotte, W., Skinner, D., \& Cain, C. (2003). Identity and agency in cultural worlds $\left(4^{\text {th }}\right.$ printing). Cambridge, NY: Harvard University Press.

Kamler, B. (2001). Relocating the personal: A critical writing pedagogy. Albany, NY: SUNY Press.

King, T. (2003). The truth about stories: A native narrative. Toronto, ON: House of 
Anansi Press.

Kress, G. (2009). Multimodality: A social semiotic approach to contemporary communication. New York: Routledge.

Lather, P. (1993). Fertile obsession: Validity after poststructuralism. Sociological Quarterly, 34, 673-693.

Luke, A. (2014). Defining critical literacy. In J. Zacher Pandya \& J. Ávila (Eds.). Moving critical literacies forward: A new look at praxis across contexts. New York: Routledge.

Mackenzie, D., \& Belliveau, G. (2011). The playwright in research-based theatre: Exploring the role of the playwright in a project on Shakespeare in the elementary classroom. Canadian Journal of Practice-Based Research in Theatre, 3, 1-23.

Saldaña, J. (Ed.). (2005). Ethnodrama: An anthology of reality theatre. Walnut Creek, CA: AltaMira Press.

Saldaña, J. (2011). Ethnotheatre: Research from page to stage. Walnut Creek, CA: Left Coast Press.

Saldaña, J. (2013). The coding manual for qualitative researchers ( $2^{\text {nd }}$ ed.). Thousand Oaks, CA: Sage.

Street, B. (1984). Literacy in theory and practice. Cambridge: Cambridge University Press.

Author Biographies

Dr. Michelle A. Honeyford is an Assistant Professor in Language \& Literacy in the Department of Curriculum, Teaching \& Learning in the Faculty of Education at the University of Manitoba.

Dr. Wayne Serebrin is an Associate Professor of Language and Literacy Education in the Curriculum, Teaching and Learning Department in the Faculty of Education at the University of Manitoba, Winnipeg, Manitoba, Canada and scholar-in-residence in Seven Oaks School Division. 